\title{
Surface orange patinas on the limestone of the Batalha Monastery (Portugal): characterization and decay patterns
}

\author{
Yufan Ding $^{1,2}$ (1) $\cdot$ Pedro Redol $^{3} \cdot$ Emma Angelini $^{2} \cdot$ José Mirão $^{1,4} \cdot$ Nick Schiavon $^{1}$ \\ Received: 17 February 2021 / Accepted: 13 July 2021 / Published online: 29 July 2021 \\ (C) The Author(s) 2021
}

\begin{abstract}
Samples of orange patinas found on a limestone window tracery and an ornament of the Batalha Monastery have been investigated by X-ray micro-diffractometry ( $\mu$-XRD) and low-vacuum scanning electron microscopy coupled with energy dispersive spectrometry (LV-SEM + EDS). The aim of the study was to determine the composition of the layered patinas, assess whether they have been intentionally applied or naturally formed, and study their degradation patterns. Preliminary results revealed that the orange patinas on the window tracery and the ornament showed different compositions and appearance, suggesting distinct formation pathways. Orange patinas on the ornament, which are now showing decay and delamination patterns, mainly consisted of gypsum with hematite as a minor component, implying the possibility of an intentional application of a mixture of ochre and lime as tint plaster. Orange patinas on the window tracery show, instead, the presence of Ca-oxalates, abundant weddellite, and minor whewellite, with minor hematite suggesting the yellowish/orange color as being due to Ca-oxalate patinas imbedding soil dust airborne particles. Such patina was possibly formed naturally either by the chemical attack due to atmospheric air pollutants from traffic exhausts emissions or by bacterial activity. No delamination was observed on the window tracery sample with granular decohesion as the major decay phenomenon. A comparison was made between this patina and the so-called scialbatura, a surface yellowish coating often found by conservators on limestone and marble in ancient monuments in the Mediterranean region.
\end{abstract}

Keywords Oolitic limestone $\cdot$ Orange patina $\cdot$ Scialbatura $\cdot$ Stone decay $\cdot$ Batalha Monastery

\section{Introduction}

The famous Batalha Monastery located in the small town of Batalha in Central Portugal was built and restored using Jurassic oolitic limestones extracted from several quarries in the region surrounding the monument (Aires-Barros 2001; Ding et al. 2019). Although originally white in color, the

Responsible editor: Michel Sablier

Yufan Ding

yding@uevora.pt

Hercules Laboratory, University of Évora, Évora, Portugal

2 Polytechnic of Turin, Turin, Italy

3 Direção Geral do Património Cultural, Mosteiro da Batalha, Batalha, Portugal

4 Department of Geosciences, University of Évora, Évora, Portugal monastery limestone is now extensively covered with orange patinas which can be seen on the surface of facades, ornaments, columns, and walls (Fig. 1). Few studies on this subject can be found in the literature. Rattazzi and coworkers examined two statues stored in the monastery museum: the external orange layers were found to show a rather homogeneous texture with traces of gypsum and clay minerals; FTIR analysis showed bands of Al-silicates and iron oxides, interpreted as Earth of Sienna natural and Red Ochre pigments (Rattazzi et al. 1996). Aires-Barros et al. investigated the original fifteenth-century Saint Matthew statue and the external walls of the main façade. The statue showed the presence of calcite with minor nitrate, silicate, and organic products like benzoic acid, while on the external walls, the orange patinas were found to be predominantly composed by calcium oxalates such as whewellite $\left(\mathrm{CaC}_{2} \mathrm{O}_{4} \cdot \mathrm{H}_{2} \mathrm{O}\right)$ with minor weddellite $\left(\mathrm{CaC}_{2} \mathrm{O}_{4} \cdot 2 \mathrm{H}_{2} \mathrm{O}\right)$, together with hydroxyapatite $\left(\mathrm{Ca}_{5}\left(\mathrm{PO}_{4}\right)_{3}(\mathrm{OH})\right)$, halloysite, and nitrates (Aires-Barros et al. 2001). 


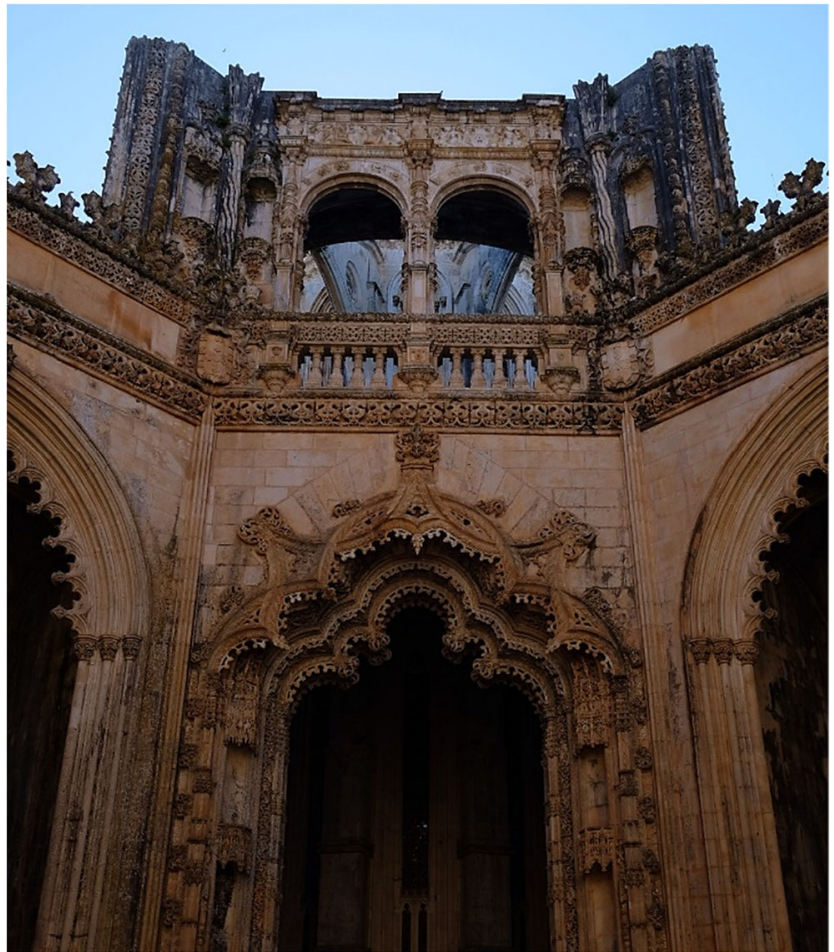

Fig. 1 Facade and ornaments with orange patina at the Imperfect Chapels, Batalha Monastery

These results suggested these patinas to represent what conservators called "scialbatura," e.g., a superficial film present as a surface coating on calcareous Greek and Roman monuments in the urban areas, colored variously yellow, brown, pink, or red and often associated with pitting phenomena (Lazzarini and Salvadori 1989). In the late 1980s, researchers demonstrated that the principal components of the "scialbatura" were Ca-oxalates (mainly weddellite and whewellite), iron oxides (ochres), calcite from the underlying marble substrate, quartz, and feldspars as a result of dry deposition of windborne soil dust, and gypsum originated from the reaction between atmospheric $\mathrm{SO}_{2}$ derived from fossil fuel, oil, and coal burning processes and the calcitic substrate (Del Monte and Sabbioni 1987). In fact, the origin of oxalate minerals found on calcitic stone surfaces in urban environments has been the subject of intense debate for decades as being due to different chemical and biogenic processes such as (a) oxalate mineral precipitation associated with chemical attack on calcite-rich substrates of oxalic acid due to metabolic activity of encrusting epilithic lichens (Del Monte et al. 1987; Schiavon 2002; Rosado et al. 2016); (b) non-bio-mediated chemical reactions between the calcareous stone substrate and a number of natural and manmade organic pollutants found in the urban atmosphere from volcanic activity and industrial production activities (Camuffo 1993), and/or vehicle exhaust emissions (Kawamura and Kaplan 1987); and (c) organic compounds used in past decorative or protective treatments and responsible for oxalate formation, such as calcium caseinate, egg, and milk (Lazzarini and Salvadori 1989; Franzini et al. 1984); "Scialbatura" patinas has been also considered to represent intentionally added "sacrificial" coating for the monuments eventually leading, though, to further stone decay (Demitry 1988). In the follow-up studies, Fassina (1995) considered lime as being the main component of the traditional "scialbatura," with, in addition, titanium oxide detected in the yellow-pink layer. The yellow color was interpreted as related to the presence of fluorite probably formed during the superficial consolidation using fluorosilicate treatments or alternatively to acid cleaning interventions.

Nearly 15 years have passed since the last research carried out on this topic. In this research, two fragments from the Batalha Monastery - an ornament and a window tracery section - have been investigated. Aim of this study was to determine the composition of the orange layers on their surface and make a comparative study between each other and with previous research. Another aim was to assess the possible interactions between the oolitic limestone substrate, the orange surface patinas, and the urban environment surrounding the Monastery.

\section{Methods and materials}

By special permission of the Direção-Geral do Patrimonio Cultural and the Mosteiro da Batalha authorities, 2 fragments were sampled from the monastery to HERCULES Laboratory (University of Evora) to carry out the characterization: one is an ornament from the west portal of the church - "S-116" (Fig. 2) from the fifteenth century, and the other is an ornament from a window tracery in the Royal Cloister (Fig. 3). These samples were both located outdoor and occasionally exposed to the sun and rain. Complying with the principle of nondestructive detection, the following analytical methods were used.

\section{Color evaluation}

Datacolor CHECK II PLUS Spectrophotometer was used to determine the color of the patina, by selecting the CIELabCH system; the color evaluation was illustrated as $\mathrm{L}, \mathrm{a}, \mathrm{b} \mathrm{c}$, and $\mathrm{H}$. By comparing the appearance of the samples with the Munsell color chart and taking $\mathrm{L}$, $\mathrm{a}$, and $\mathrm{b}$ values as references, color number that is most similar to the presented patinas is selected.

\section{Optical microscope}

Samples were observed under LEICA M205C Stereo Microscope (Leica, Wetzlar, Germany). A peeled-off fragment of sample S-116 was consolidated with resin and polished, for the observation of the cross-section. 


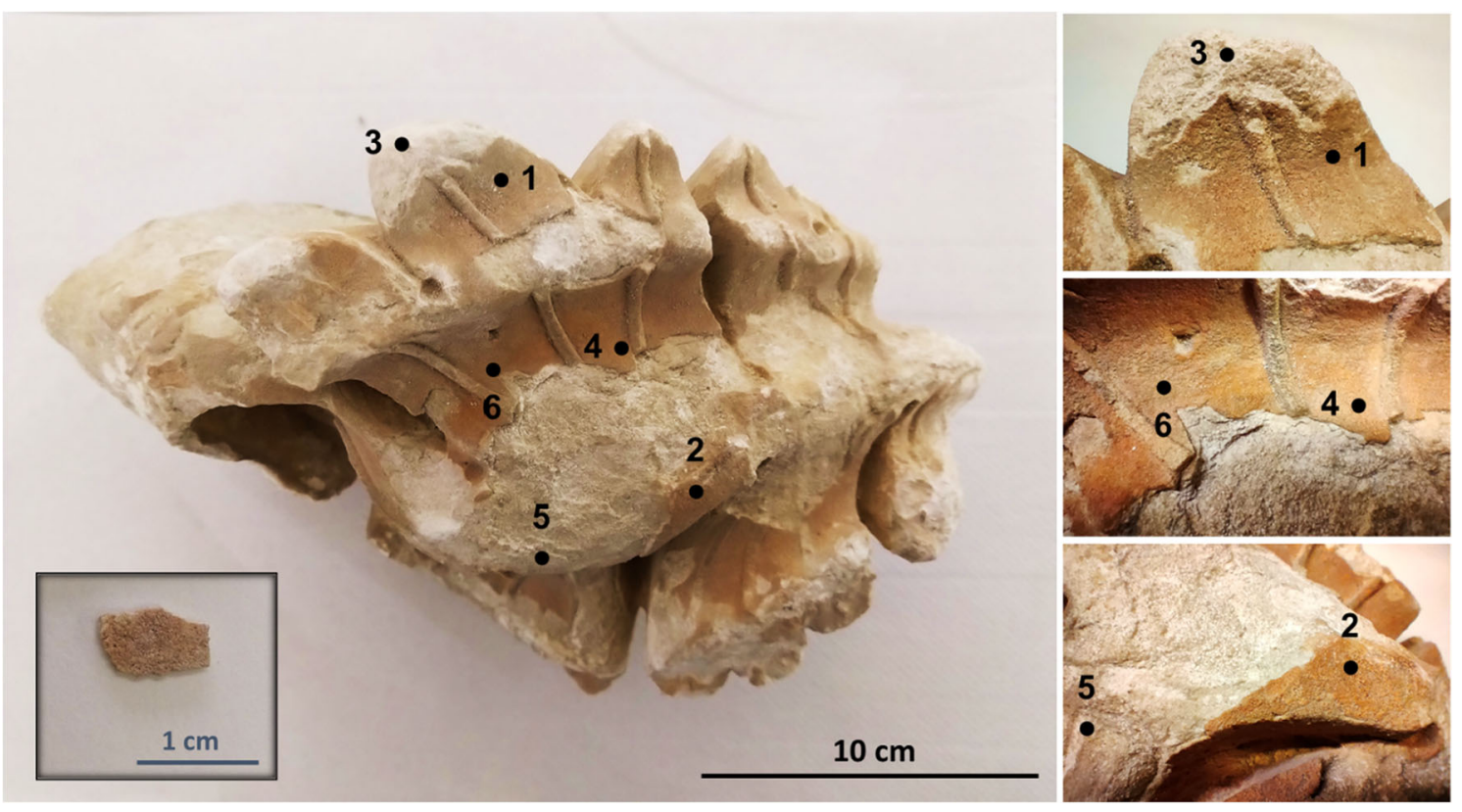

Fig. 2 Ornament "S-116" and the peeled-off surface fragment

\section{X-ray micro-diffractometry ( $\mu$-XRD)}

Multiple points on the orange layer and the substrate of the samples (Fig. 2 and Fig. 3) were characterized by $\mu$-X-ray diffraction using a commercial Bruker AXS D8 Discovery diffractometer with $\mathrm{Cu}$ Ka radiation, Lynxeye detector, interval $3-70^{\circ} 2 \mu$, and step of $0.028 / \mathrm{s}$. DIFFRAC.SUITE EVA and Highscore Plus software were used to identify the mineralogical composition and to perform a semi-quantification by the RIR method (Hubbard and Snyder 1988).

\section{Variable-pressure scanning electron microscopy coupled with energy dispersive spectrometry (VP-SEM + EDS).}

Scanning electron microscopy coupled with energy dispersive X-ray spectrometry was carried out using a Hitachi S3700N (Tokyo, Japan) SEM coupled to a Bruker (Karlsruhe, Germany) XFlash 5010 SDD Detector system (Veiga et al. 2014). The samples were characterized at a chamber pressure of $40 \mathrm{~Pa}$, without any sample preparation, with an accelerating
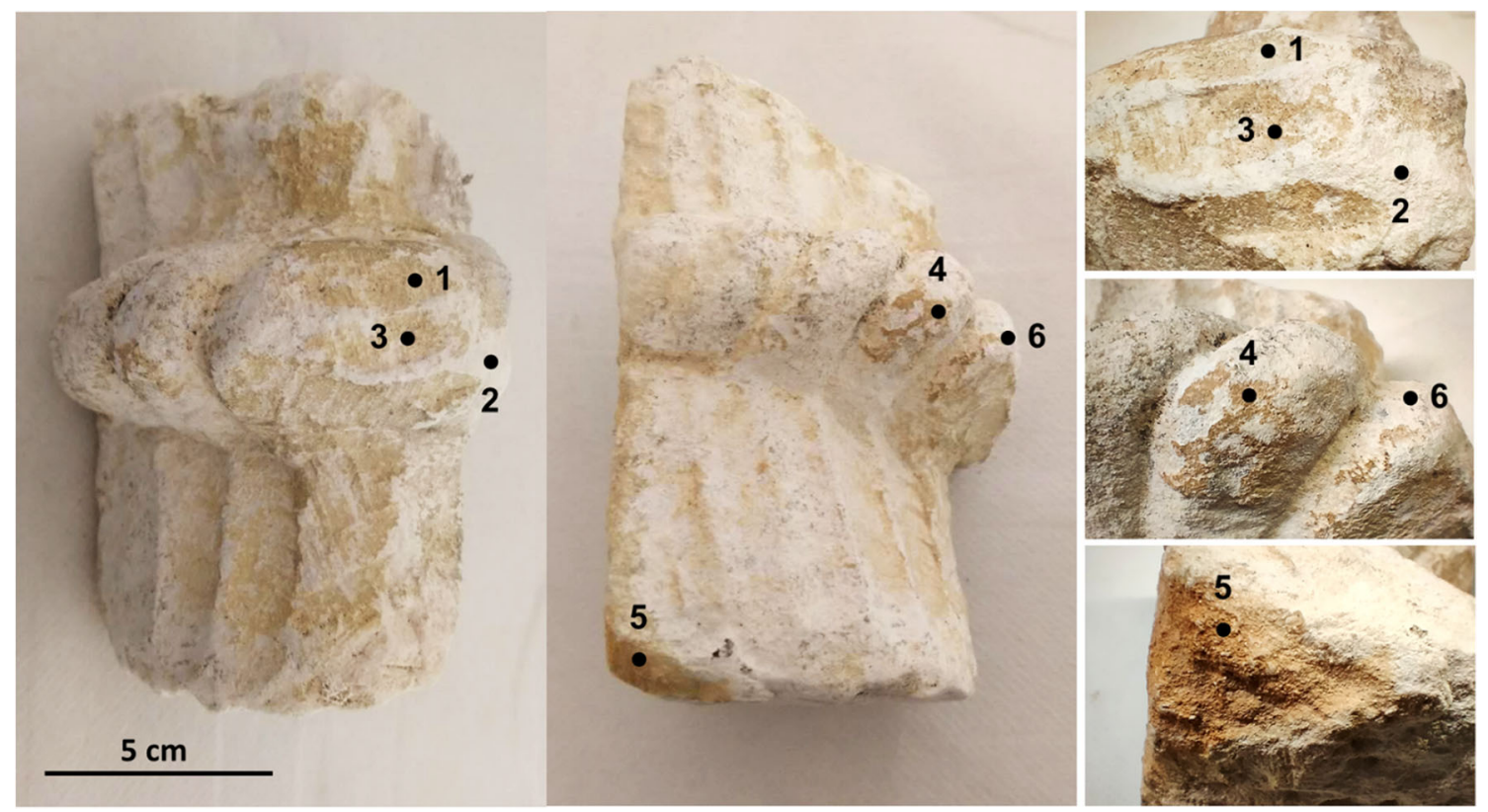

Fig. 3 Window tracery piece from the Royal Cloister of the Monastery 
voltage of $20 \mathrm{kV}$, using a working distance $10 \mathrm{~mm}$ and a BSEM detector.

\section{Results and discussion}

The photographs of the sample S-116 and window tracery piece are presented in Fig. 2 and Fig. 3, respectively. Microscopy was performed on these two samples, and the pictures are shown in Fig. 4. It can be seen that the orange color of the patina on S-116 is more saturated than that of window tracery sample. The patina on the window tracery surface is unevenly distributed, and its color also shows variegation over the area (Fig. 4b). On the contrary, the patina on the ornament S-116 is much more homogenous, and the color is consistent over the patina covered region (Fig. 4a). Crosssection observation revealed that the peeled-off fragment consists of a $0.1 \sim 0.2 \mathrm{~mm}$ orange layer and $1 \sim 1.2 \mathrm{~mm}$ oolitic

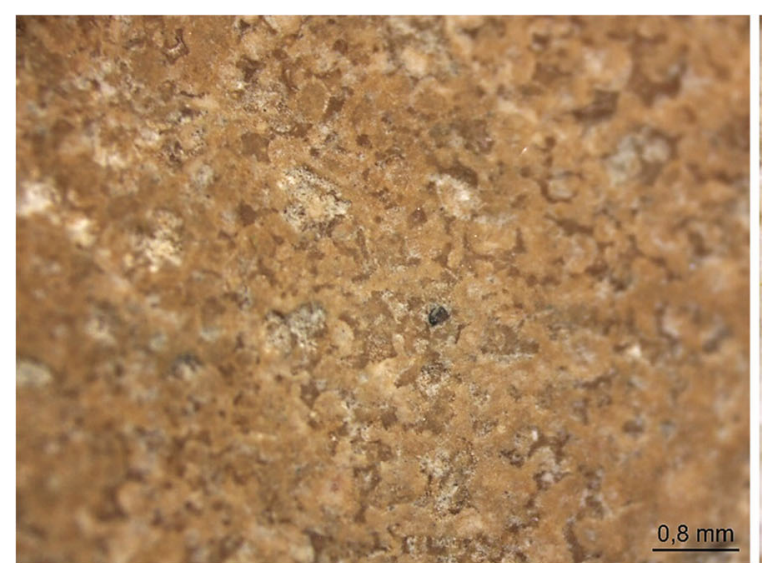

$\mathbf{a}$

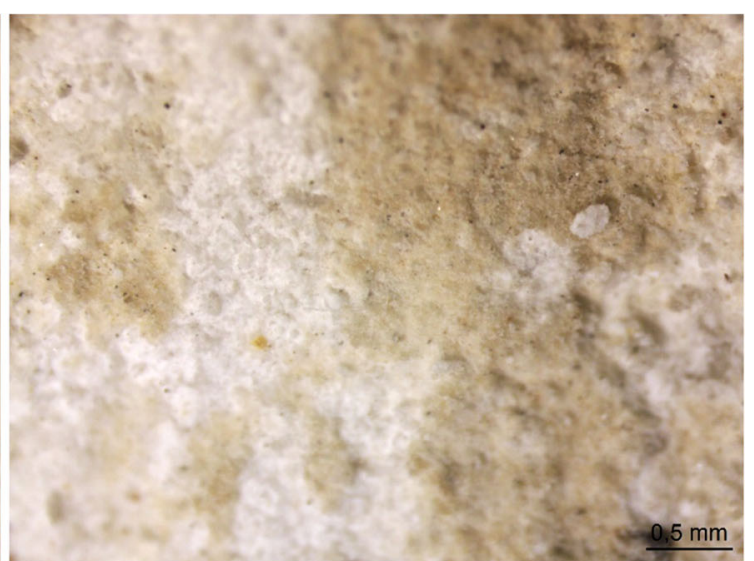

b

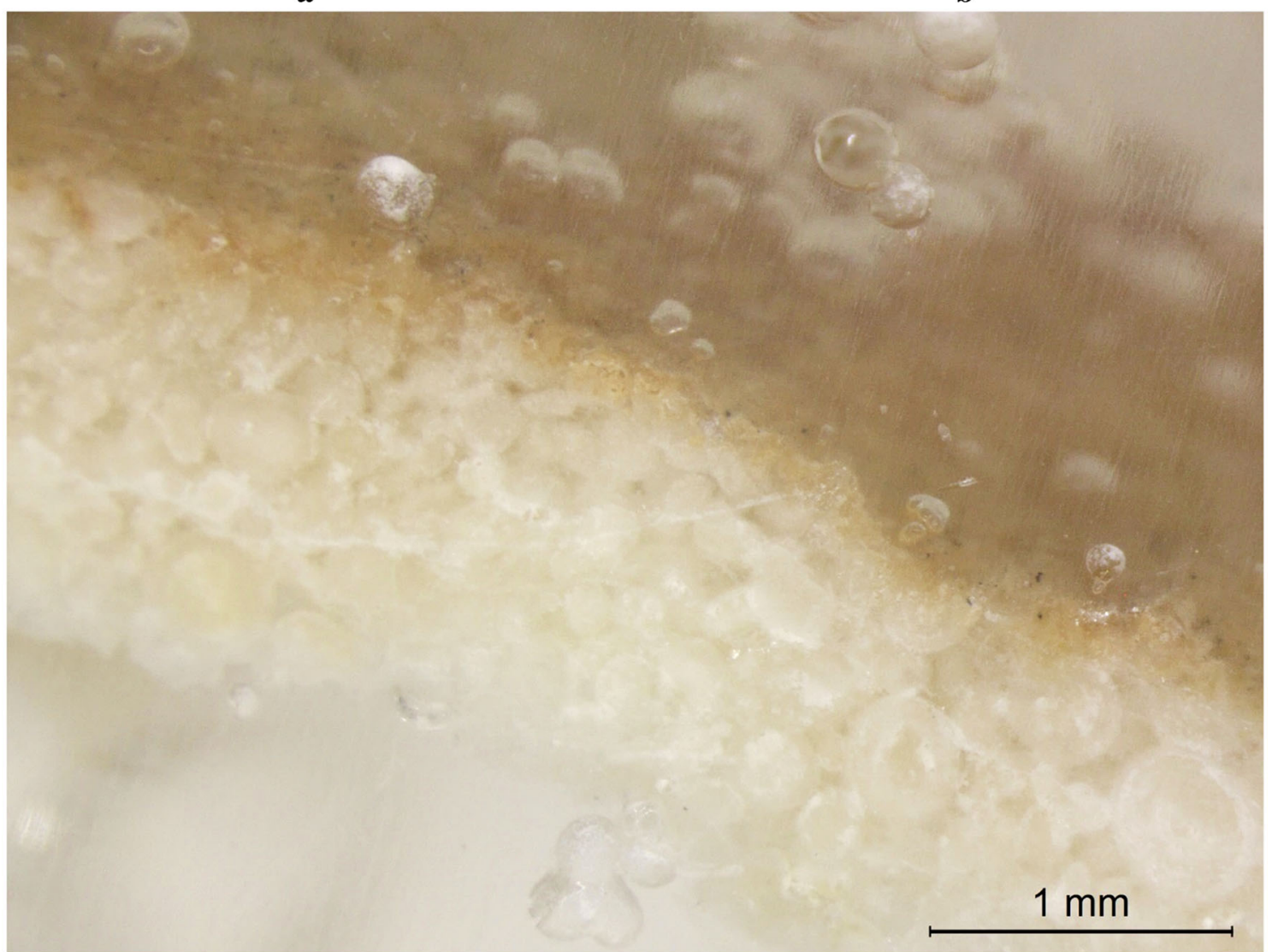

c

Fig. 4 Optical microscope photos of a sample S-116 surface, $\mathbf{b}$ the window tracery sample surface, and $\mathbf{c}$ cross-section of the peeled-off fragment from sample S-116 
limestone substrate, and the fragment has thickness of $\sim 1.3 \mathrm{~mm}$ (Fig. 4c), implying that the detachment of this coating happens under the limestone surface.

\section{Ornament "S-116" from Batalha Monastery}

The color evaluation of the patina on sample S-116 is L: 68.63, a: 9.66, b: 15.67, C: 16.56, and H: 66.04. MUNSELL $2.5 \mathrm{YR} / 6 / 6$ is very close to this color.

$\mu$-X-ray diffraction patterns were acquired on six points of the ornament "S-116" and a peeled-off fragment, as shown in Fig. 2. Points 1, 2, 4, and 6 were acquired on the orange surface patinas, whereas points 3 and 5 were acquired on the substrate where the orange surface had already peeled off with the limestone substrate showing extensive decay. The XRD pattern and peaks are presented in Fig. 5, and a semiquantitative evaluation is given in Table 1.

In both samples, the stone substrate is an oolitic limestone consisting mainly of calcite and quartz (Ding et al. 2019): accordingly, peaks of both minerals are seen at all points analyzed. A considerable amount of gypsum can be detected at points $1,2,4$, and 6 and in the detached fragment, in areas corresponding to the orange surface, while at points 3 and 5 where the coating is completely removed, gypsum is absent. Halite was present in all analyzed spots, with its content being significantly higher at points 3 and 5 , indicating that halite was concentrated on the substrate surface under the orange layer. Feldspar peaks (Al-K-silica) were present particularly at point 1 , confirming the presence of soil dust deposition in this area. A minor amount of hematite was detected in all orange patinas suggesting the presence of red ochre pigment.

The sporadic presence of ettringite peaks in XRD results is somewhat intriguing. The presence of ettringite could be due to the cementitious materials exposed to sulfate attack: calcium aluminate hydrates and calcium silicate hydrates mixed with lime can react with water and gypsum or other sulfate salts, to produce ettringite $\left[\mathrm{Ca}_{6} \mathrm{Al}_{2}\left(\mathrm{SO}_{4}\right)_{3}(\mathrm{OH})_{12} \cdot 26 \mathrm{H}_{2} \mathrm{O}\right]$ and thaumasite $\left[\mathrm{Ca}_{3} \mathrm{Si}(\mathrm{OH})_{6}\left(\mathrm{CO}_{3}\right)\left(\mathrm{SO}_{4}\right) 12 \mathrm{H}_{2} \mathrm{O}\right]$ (Collepardi 1999). The application of cement-based mortar in the Batalha monastery during past restoration interventions (Soares 2001) could therefore explain the presence of ettringite on the ornament surface.

The peeled-off fragment was observed under the VPSEM+EDS: results are shown in Fig. 6. There is a correlation between the distribution of sodium and chloride, demonstrating the presence of halite $(\mathrm{NaCl})$ grains. Potassium $(\mathrm{K})$, aluminum (Al), and silicon ( $\mathrm{Si}$ ) peaks imply the presence of quartz, feldspar, and clay minerals probably as soil dust. The peak of calcium $(\mathrm{Ca})$ is weak where the $\mathrm{NaCl}$ and feldspar/soil dust/clay grains are present, which means halite and aluminosilicates were formed subsequently on the top of the limestone substrate. This could also be seen from the SEM picture; the halite (up left) and feldspar (down central) show a wellformed crystalline habit with relatively large dimension grains $(>50 \mu \mathrm{m})$, in contrast with the poorly crystallized gypsum grains.

The distribution of iron $(\mathrm{Fe})$ was homogenous over the whole analyzed area, supporting the interpretation of a pigment surface application. On the other hand, hematite is also present as accessory mineral grains in the original limestone. The presence of sulfur ( $\mathrm{S}$ ) is mainly due to gypsum $\left(\mathrm{CaSO}_{4} \cdot 2 \mathrm{H}_{2} \mathrm{O}\right)$; its distribution is uniform, and some multimineral grains can be seen. By overlapping the distribution of Fe and S (Fig. 7), it can be seen that hematite was likely to be mixed and applied together with gypsum on the uppermost layer. This hypothesis can be supported by the recorded use of red and yellow ochre: in ancient Macedonian paintings, one of the main means of using ochre was to mix them with lime to produce tint plasters which were then applied at the surface of monuments (Perdikatsis and Brecoulaki 2008). Gypsum plaster might have been applied in the lime to achieve faster setting time. Therefore, the color on the ornament "S-116"

Table. 1 Qualitative and semi-quantitative list of minerals and compounds detected on the ornament "S-116" surface

\begin{tabular}{|c|c|c|c|c|c|c|c|}
\hline \multirow[t]{2}{*}{ Composition } & \multicolumn{7}{|l|}{ Appearance } \\
\hline & $\begin{array}{l}\text { Orange } \\
\text { surface }\end{array}$ & $\begin{array}{l}\text { Orange } \\
\text { surface } \\
\text { with dust }\end{array}$ & $\begin{array}{l}\text { Orange } \\
\text { surface }\end{array}$ & $\begin{array}{l}\text { Weathered white } \\
\text { substrate }\end{array}$ & $\begin{array}{l}\text { Orange } \\
\text { surface }\end{array}$ & $\begin{array}{l}\text { Weathered white } \\
\text { substrate }\end{array}$ & $\begin{array}{l}\text { Orange } \\
\text { surface }\end{array}$ \\
\hline Calcite $\left(\mathrm{CaCO}_{3}\right)$ & $81 \%$ & $40 \%$ & $74 \%$ & $70 \%$ & $73 \%$ & $72 \%$ & $68 \%$ \\
\hline $\begin{array}{l}\text { Gypsum } \\
\quad\left(\mathrm{CaSO}_{4} \cdot 2 \mathrm{H}_{2} \mathrm{O}\right)\end{array}$ & $7 \%$ & $20 \%$ & $8 \%$ & - & $19 \%$ & - & $9 \%$ \\
\hline Quartz $\left(\mathrm{SiO}_{2}\right)$ & $2 \%$ & $4 \%$ & $5 \%$ & $7 \%$ & $3 \%$ & $7 \%$ & $6 \%$ \\
\hline Hematite $\left(\mathrm{Fe}_{2} \mathrm{O}_{3}\right)$ & $1 \%$ & $5 \%$ & $2 \%$ & $2 \%$ & $3 \%$ & - & $14 \%$ \\
\hline Halite $(\mathrm{NaCl})$ & $1 \%$ & $5 \%$ & $4 \%$ & $21 \%$ & $2 \%$ & $21 \%$ & $3 \%$ \\
\hline Ettringite & $8 \%$ & - & $7 \%$ & - & - & - & - \\
\hline Feldspar $\left(\mathrm{KAlSi}_{3} \mathrm{O}_{8}\right)$ & - & $26 \%$ & - & - & - & - & - \\
\hline
\end{tabular}




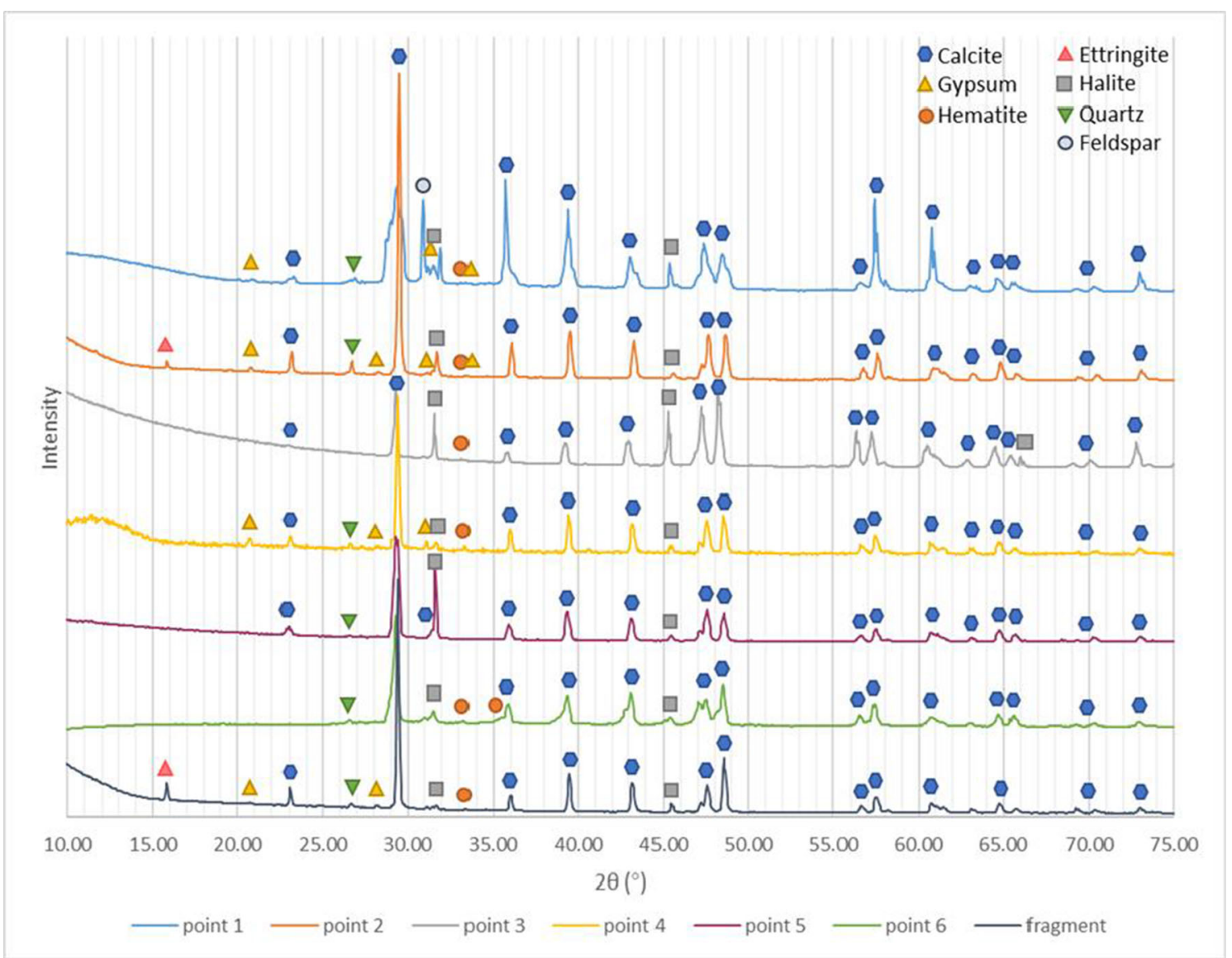

Fig. 5 XRD results of multiple points on ornament "S-116" and the peeled-off fragment

surface could be the reason of the same procedure. It is noteworthy the presence of phosphorous $(\mathrm{P})$, which was also detected by Lazzarini and Salvadori (1989) on the "scialbatura" of Cathedral and church of S. Zeno, Verona, and interpreted as an artificial protective coating made from calcium caseinate.

\section{Window tracery from Batalha Monastery Royal Cloister}

The color evaluation of the patina on the cloister window tracery is L: 85.24 , a: 3.97 , b: $15.46, \mathrm{C}: 15.96$, and $\mathrm{H}: 75.58$. MUNSELL $5 \mathrm{YR} / 8 / 6$ is very close to this color.

The window tracery sample was analyzed only by microXRD to prevent causing any damage. XRD results of multiple points on the Royal Cloister window tracery shows the XRD pattern, and in Table 2, the main minerals are listed together with their semi-quantitative evaluation. At point 1, where an orange surface is still visible, abundant calcium oxalate was present including weddellite and whewellite, together with feldspar and hematite. Gypsum was detected where the orange surface was worn-out and detached revealing the underlying white substrate. In these areas, the main composition was calcite with minor amount of gypsum and calcium oxalate and no detected hematite. Point 3 has a different appearance than point 1 , the surface showing a dark orange color, and the texture being loose and powdery in this area; the XRD results revealed calcite, some weddellite, feldspar, and minor hematite. Halite was present at point 3 and absent at points 1 and 2 .

Calcium oxalate is itself colorless, but when organic compounds, mainly derived from the metabolic activity of lichens, fungi, and bacteria (from oxalic acid which reacts with calcite to form a thin calcium oxalate film) and other mineral grains (such as quartz and feldspar) are present, the patina may acquire a yellowish-brown hue (Ion et al. 2017). Thus, the color on this window tracery could possibly originate from calcium oxalate mixed with other mineral grains such as soil dust. The stone surface oxalates were generally considered to be the result of lichen excreted oxalic acid that reacts with calcium in the substrate (Del Monte et al. 1987); however, a few recent studies reported that various bacteria can produce oxalic acid even without lichen microbiomes, for instance, Pseudomonas fluorescens, Burkholderia, Bacillus, and C. jiangningensis JN53 (Palmieri et al. 2019; Hess et al. 2008; Cheng et al. 2017). In fact, Bacillus (phylum Firmicutes) and Burkholderia (phylum Beta-Proteobacteria) were found in the Batalha Monastery bio-deteriorated stone and the atmospheric environment in a previous study by the same authors (Ding et al. 2021). Thus, although no lichen crust was present 


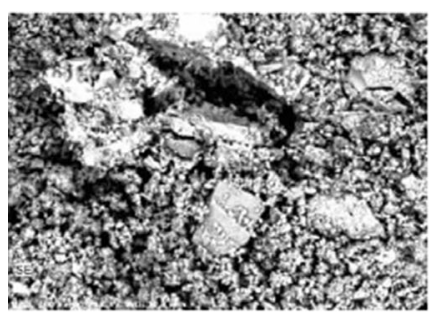

SEM

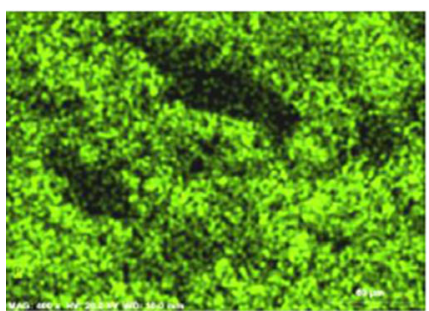

$\mathbf{P}$

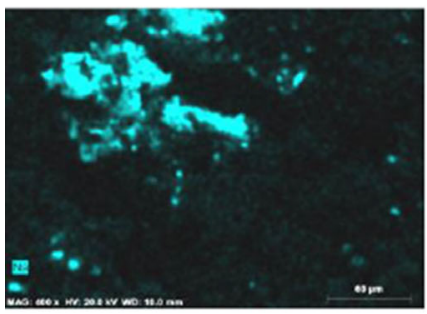

Na

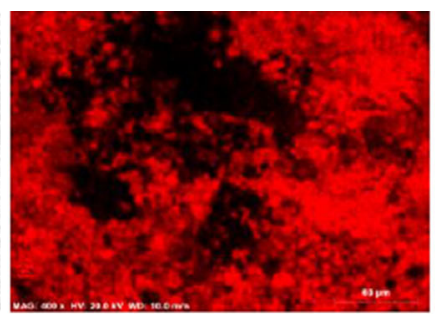

Ca

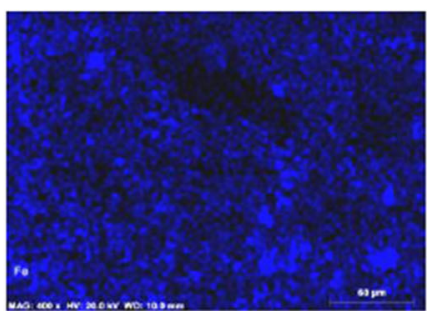

Fe

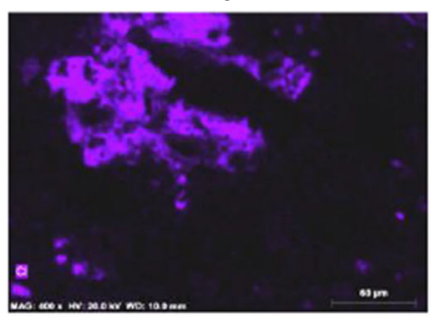

Cl

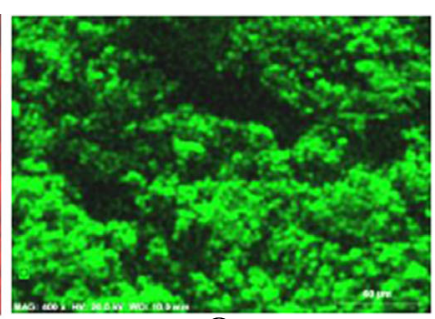

$\mathbf{O}$

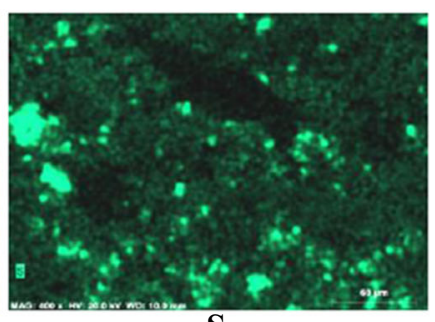

S

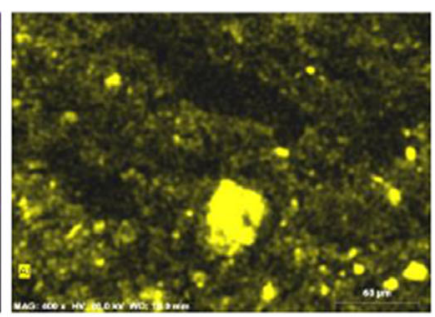

Al

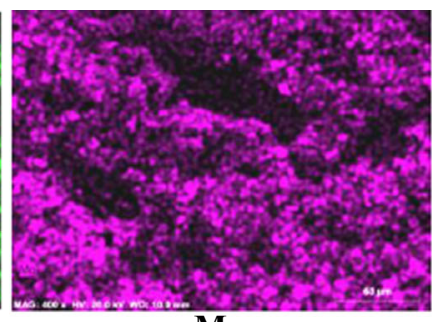

Mg

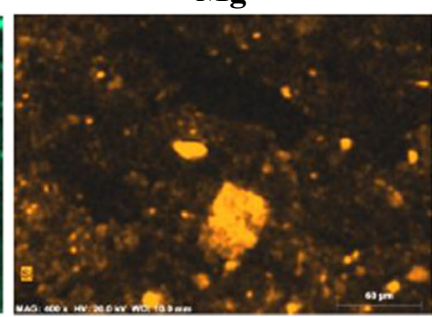

Si

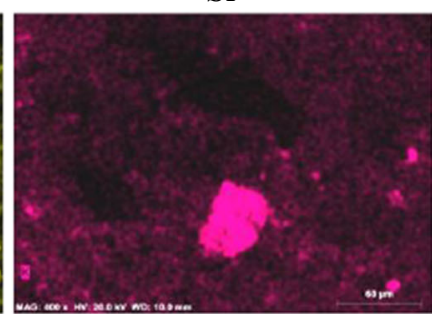

K

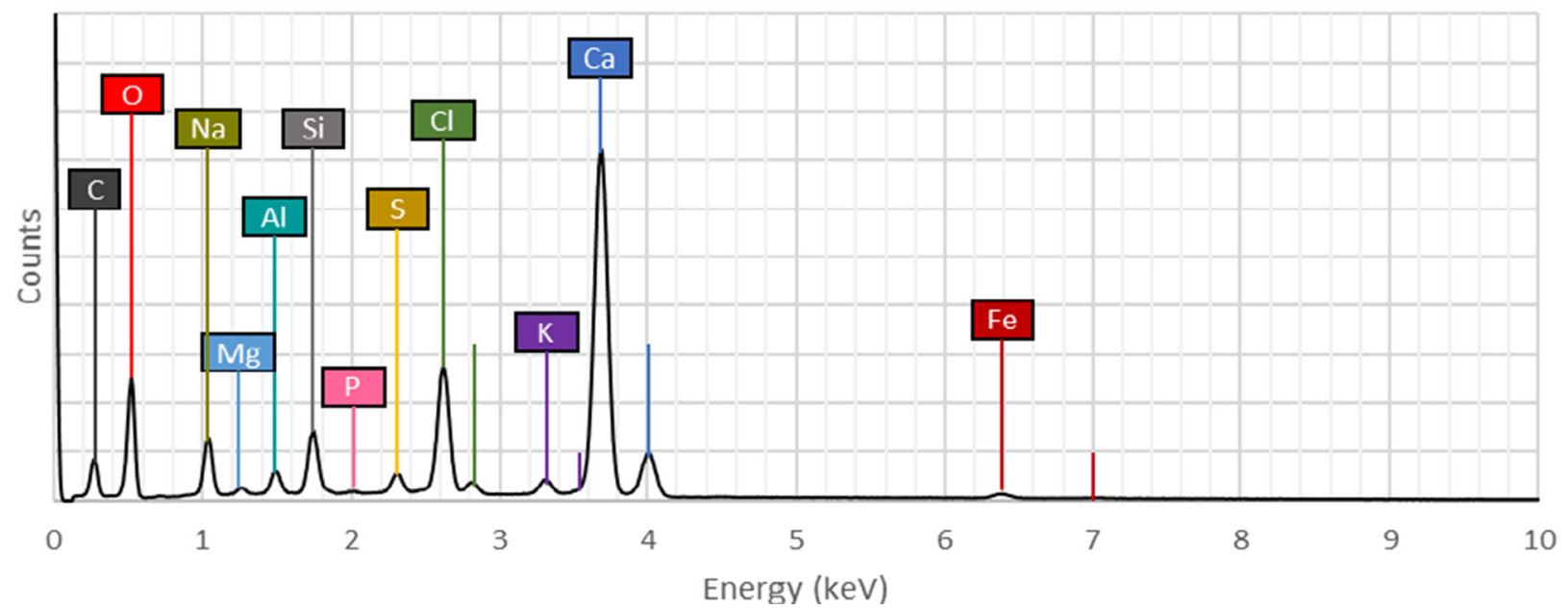

Fig. 6 SEM-EDS element mapping of ornament "S-116" fragment

on this Window tracery sample, the possibility of bacteria producing oxalic acid and causing mineral weathering cannot be excluded (Fig. 8).

Calcium oxalates may also be derived from vehicular exhaust emissions with incomplete combustion of aromatic hydrocarbons (such as benzene, toluene, and naphthalene) in the car engines generating diacids including oxalic acid, cisunsaturated acids, and aromatic acids (Kawamura and Kaplan 1987). Due to the polar nature of these dicarboxylic acids, they preferentially associate with moisture and could react with calcareous stone and form calcium oxalates. As a matter of fact, the Portuguese national highway IC2 run through Batalha only $50 \mathrm{~m}$ west of the monastery, so atmospheric vehicular pollution could not be ruled out as a cause for the development of oxalate patinas on the limestone surfaces of the monastery. The benzoic acid found by AiresBarros et al. (2001) on the external walls of this monument makes this hypothesis more plausible. 
Fig. 7 Overlapped element mapping of $\mathrm{Fe}$ (blue) and $\mathrm{S}$ (neon green) with the morphology photo

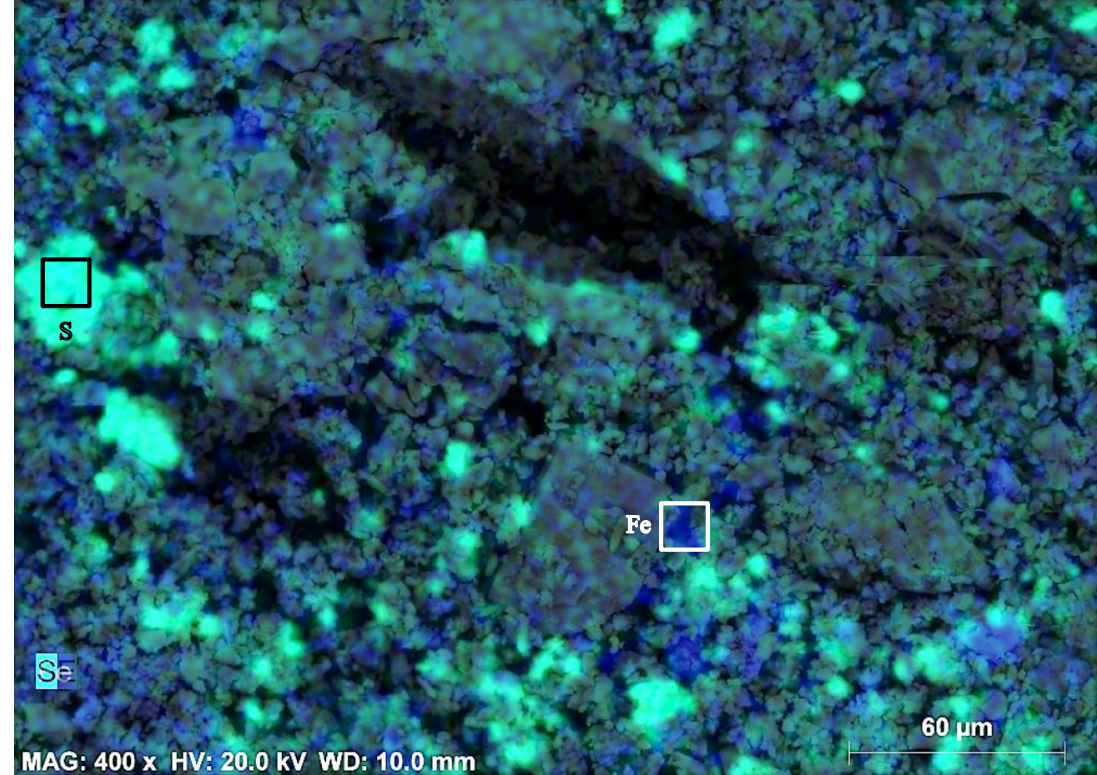

\section{Comparison between the two samples}

Though both named "orange patinas," there are significant differences between the two samples investigated. Table 3 lists these differences with respect to composition, appearance, and decay patterns. For the ornament "S-116," the orange layer follows the external geometrical shape of the object, for example, the ridging stripes spreading out from the center, which also existed on the substrate. For the Royal Cloister window tracery, the orange patina is closely adherent to the limestone substrate instead of a visible separate layering present on "S-116." And there was an abundant weddellite on the window tracery surface, which was not found on the sample "S-116."

The decay pattern of these orange layers on the two samples was also distinct. On the ornament "S-116," the surface layer was flaking; on the white substrate under the peeled-off lamination, higher content of halite was detected. This indicates a typical salt decay process: salt solution evaporated and crystallized at the interface between the coating and the substrate, leading to detachment eventually (Duffy and Perry 1996). In this case, the salt responsible for decay is mainly halite $(\mathrm{NaCl})$; its precipitation leading to salt decay in the monastery may probably derive from ground-moisture capillary rise. Considering the Royal Cloister window tracery, the patina was lost preferentially at the ridges and bulges but was more preserved in flat areas where marks of scratches can also be seen. Three possible explanations can be suggested: (a) the evaporation rate of salt solutions is higher at the geometrically protruded parts due to a larger specific surface area, resulting in higher crystallization pressure inside the stone pores and more severe decay (Rodriguez-Navarro and Doehne 1999); (b) protruded areas endure more mechanical abrasion from

Table. 2 Qualitative and semi-quantitative list of minerals and compounds detected on the window tracery

\begin{tabular}{|c|c|c|c|c|c|c|}
\hline \multirow[t]{2}{*}{ Composition } & \multicolumn{6}{|l|}{ Appearance } \\
\hline & Orange surface & White substrate & Orange surface & Orange surface & $\begin{array}{l}\text { Orange surface } \\
\text { loose texture }\end{array}$ & White substrate \\
\hline Calcite $\left(\mathrm{CaCO}_{3}\right)$ & $54 \%$ & $80 \%$ & $15 \%$ & $38 \%$ & $85 \%$ & $100 \%$ \\
\hline Gypsum $\left(\mathrm{CaSO}_{4} \cdot 2 \mathrm{H}_{2} \mathrm{O}\right)$ & $18 \%$ & $9 \%$ & $39 \%$ & $19 \%$ & $3 \%$ & - \\
\hline Weddellite $\left(\mathrm{CaC}_{2} \mathrm{O}_{4} \cdot 2 \mathrm{H}_{2} \mathrm{O}\right)$ & $17 \%$ & $10 \%$ & $31 \%$ & $37 \%$ & $7 \%$ & - \\
\hline Whewellite $\left(\mathrm{CaC}_{2} \mathrm{O}_{4} \cdot \mathrm{H}_{2} \mathrm{O}\right)$ & $9 \%$ & - & $12 \%$ & - & - & - \\
\hline Quartz $\left(\mathrm{SiO}_{2}\right)$ & $2 \%$ & $1 \%$ & $3 \%$ & $6 \%$ & $2 \%$ & - \\
\hline Hematite $\left(\mathrm{Fe}_{2} \mathrm{O}_{3}\right)$ & - & - & - & - & $1 \%$ & - \\
\hline Halite $(\mathrm{NaCl})$ & - & - & - & - & $2 \%$ & - \\
\hline
\end{tabular}




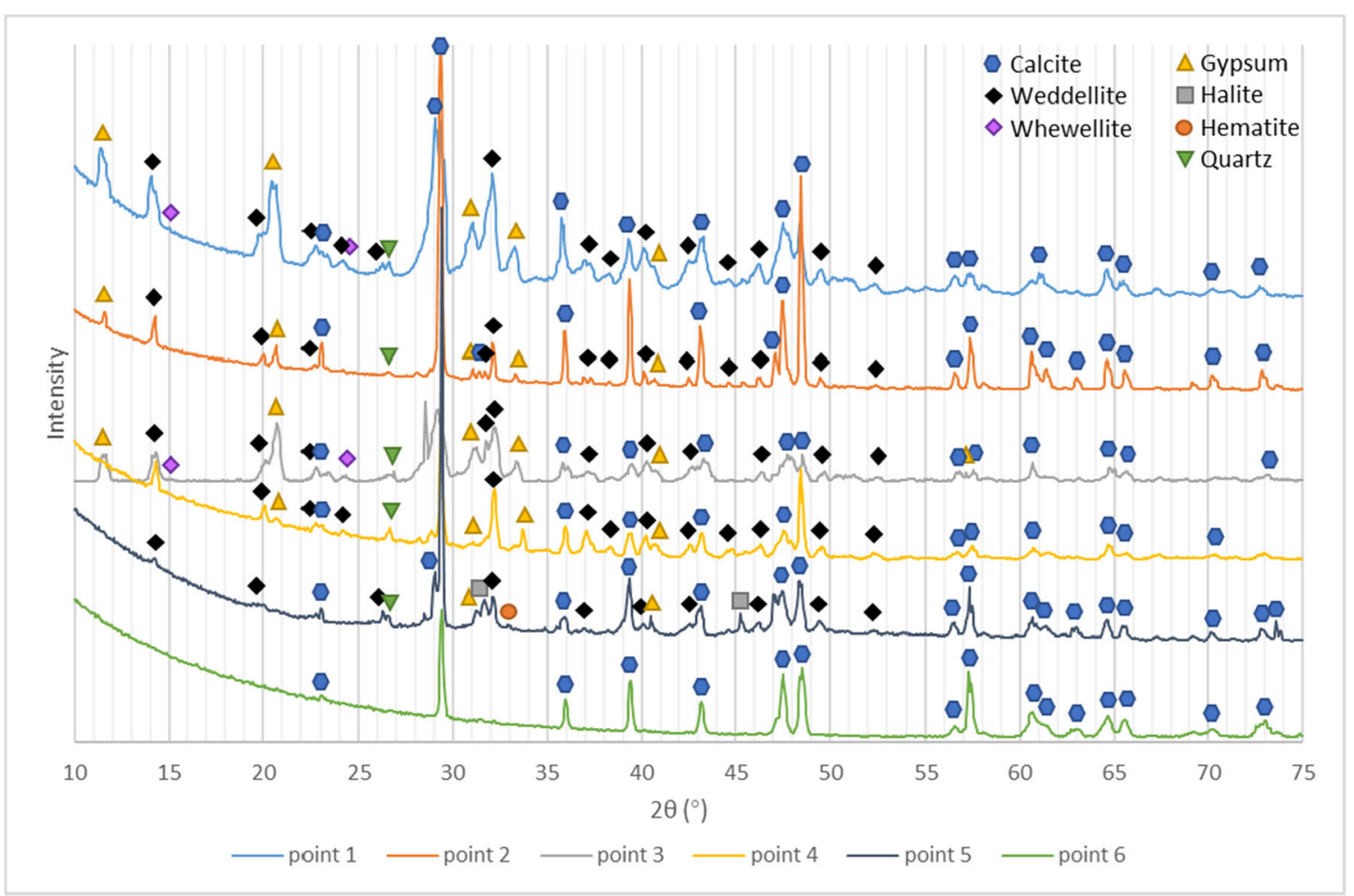

Fig. 8 XRD results of multiple points on the Royal Cloister window tracery

rain, wind, sands, and human activities, thus accelerating the decay processes; or (c) the orange patina was originally formed irregularly on the substrate.

Combining the results obtained, preliminary sketch (Fig. 9) was made to elucidate the different characteristics of the two samples investigated.

\section{Comparison with the previous research}

Through the above-mentioned results and analysis, it can be concluded that the orange layer on the Royal Cloister window tracery is similar to the findings by Aires-Barros et al. (2001). Such patina is compatible with a "scialbatura" nature for its composition, texture, and color, as described by Lazzarini and
Salvadori (1989). No titanium oxide and fluorite presence as reported in previous research (Fassina 1995). The results of the present study are in line with the conclusion that the presence of calcium oxalates on this monastery could be linked to either vehicular exhaust emissions (Kawamura and Kaplan 1987) or to bacterial activity (Palmieri et al. 2019), but not to oxalic production by lichenous colonization and its reaction with the calcite-rich stone surface (Del Monte and Sabbioni 1987; Schiavon 2002).

The orange coating on the ornament "S-116" sample matches the description of that on the original apostle statues from the church doorway (Rattazzi et al. 1996). Considering the ornament "S-116" and the apostle statues were both crafted in the fifteenth century, it is feasible to consider that

Table. 3 Comparison between the orange patinas on the sample "S-116" and on the Royal Cloister Window tracery.

\begin{tabular}{|l|l|l|}
\hline Composition & $\begin{array}{l}\text { Gypsum and hematite, with minor ettringite and } \\
\text { aluminosilicates. No calcium oxalates. }\end{array}$ & Abundant weddellite and whewellite on the surface. \\
\hline Appearance & $\begin{array}{l}\text { The orange layer has an imprint of shaping, } \\
\text { homogenous in color and thickness, it shows } \\
\text { obvious lamination from the substrate. }\end{array}$ & $\begin{array}{l}\text { The orange patina is closely adherent to the limestone } \\
\text { substrate, no visible separate lamination, the color is } \\
\text { not uniform on the surface. }\end{array}$ \\
\hline Decay Pattern & $\begin{array}{l}\text { Surface layer is flaking, a higher content of halite } \\
\text { and nitratine were detected from the white substrate } \\
\text { under the peeled off lamination, indicating a typical } \\
\text { salt decay process. }\end{array}$ & $\begin{array}{l}\text { Patina is lost preferentially at the ridges and bulges, } \\
\text { scratches can be seen. It could be due to a higher } \\
\text { crystallization pressure of salt solution at protruded } \\
\text { parts, or the protrusion endures more natural and } \\
\text { artificial mechanical attack. }\end{array}$ \\
\hline
\end{tabular}




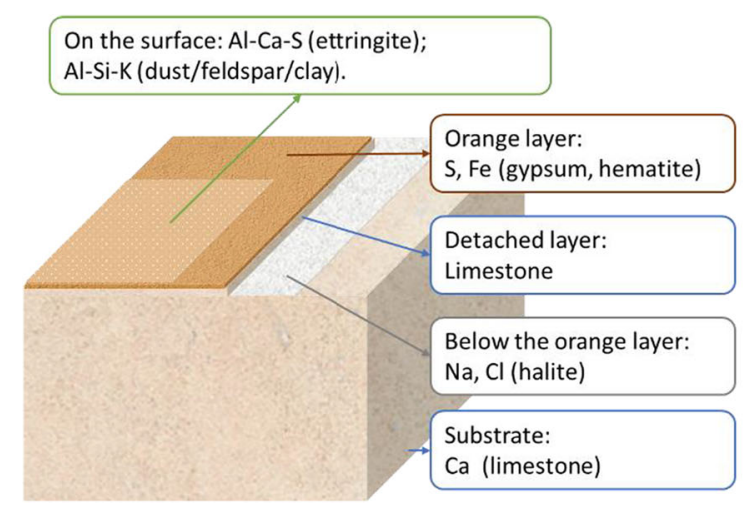

Fig. 9 Sketch of the sample "S-116" (left) and the Window tracery (right)

the same coating procedure was used, despite them being located in different sites of the Batalha Monastery. Although it is commonly believed that in this type of surface layers, the gypsum occurring on calcareous stones is a reaction product of calcareous or silicate stones in a $\mathrm{SO}_{2}$-polluted urban atmosphere (Schiavon 2007), the possibility of artificial gypsum coating cannot be completely excluded (Sánchez et al. 2009). In fact, the homogeneity of the layers and the presence of hematite may support the conclusion of the intentional application of a pigmented plaster.

\section{Conclusion}

In this research, a chemical/mineralogical characterization was carried out on orange surface patinas found in two different limestone artifacts from Batalha Monastery in Portugal. The homogenous and decorative layer on ornament "S-116" is mainly composed of gypsum and hematite with traces of Kfeldspars possibly from soil dust and mortar joints in the monument. It is highly likely to be applied intentionally, using the same craft procedure as the apostle statues of the monastery. Its delamination is a typical phenomenon of salt decay, for high concentration of halite was found on the substrate under the exfoliated surface.

The colored surface of the Royal Cloister Window tracery contains abundant calcium oxalate including weddellite and whewellite; gypsum was also detected. The surface color was not homogeneous on the window tracery piece where erosive episodes led to surface loss. Based on the above results, this surface layer was compatible with the description of "scialbatura," as it shows evidence of substrate stone reacting with the environment. This patina was likely generated due to the air pollution and the bacterial metabolic activities.

Acknowledgements Sample collection in this research was by special permission of the Direção-Geral do Patrimonio Cultural and the Mosteiro da Batalha authorities. The research presented in this paper was carried out mainly using data collected at Universidade de Évora,

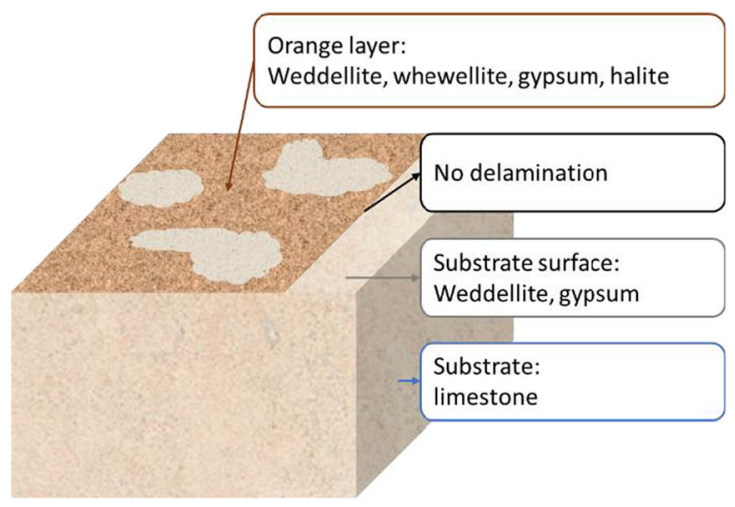

Politecnico di Torino, and Direcao-Geral do Patrimonio Cultural, as part of H2020-MSCA-ITN-2017, ED-ARCHMAT (ESR1).

Author's contribution Conceptualization: Nicola Schiavon, José Mirão, and Yufan Ding. Methodology: Nicola Schiavon, José Mirão, and Yufan Ding. Formal analysis and investigation: Yufan Ding and Nicola Schiavon. Writing - original draft preparation: Yufan Ding. Writing review and editing: Pedro Redol, Nicola Schiavon, and Yufan Ding. Funding acquisition: Nicola Schiavon and Yufan Ding. Resources: Pedro Redol. Supervision: Nicola Schiavon and Emma Angelini.

Funding This research has received funding from the European Union's Horizon 2020 research and innovation program under the Marie Skłodowska-Curie grant agreement No 766311.

Availability of data and materials Data is contained within the article.

\section{Declarations}

Ethics approval and consent to participate Not applicable for this study.

Consent to publish All authors consent to this publication.

Competing interests The authors declare no competing interests.

Open Access This article is licensed under a Creative Commons Attribution 4.0 International License, which permits use, sharing, adaptation, distribution and reproduction in any medium or format, as long as you give appropriate credit to the original author(s) and the source, provide a link to the Creative Commons licence, and indicate if changes were made. The images or other third party material in this article are included in the article's Creative Commons licence, unless indicated otherwise in a credit line to the material. If material is not included in the article's Creative Commons licence and your intended use is not permitted by statutory regulation or exceeds the permitted use, you will need to obtain permission directly from the copyright holder. To view a copy of this licence, visit http://creativecommons.org/licenses/by/4.0/.

\section{References}

Aires-Barros L, Basto MJ, Dionísio A, Charola AE (2001) Orange coloured surface deposits on stones from the Monastery of Batalha (Portugal) and from nearby historic quarries: characteristics and 
origins. Intl J Restor Build Monum 7(5):491-506. https://doi.org/10. 1515/rbm-2001-5594

Aires-Barros L (2001) As rochas dos monumentos portugueses: tipologias e patologias. volume II, 453-471. Instituto Português do Património Arquitectónico. ISBN-13: 9789728087814

Camuffo D (1993) Reconstructing the climate and the air pollution of Rome during the life of the Trajan Column. Sci Total Environ 128(2-3):205-226

Cheng C, Wang Q, He L, Sheng X (2017) Change in mineral weathering behaviors of a bacterium Chitinophaga jiangningensis JN53 under different nutrition conditions. J Basic Microbiol 57(4):293-301. https://doi.org/10.1002/jobm.201600652

Collepardi M (1999) Thaumasite formation and deterioration in historic buildings. Cement and Concrete Composites 21(2):147-154. https://doi.org/10.1016/S0958-9465(98)00044-4

Del Monte M, Sabbioni C (1987) A study of the patina called 'scialbatura' on imperial Roman marbles. Stud Conserv 32(3): 114-121. https://doi.org/10.1179/sic.1987.32.3.114

Del Monte M, Sabbioni C, Zappia G (1987) The origin of calcium oxalates on historical buildings, monuments and natural outcrops. Sci Total Environ 67(1):17-39

Demitry, L. (1988). The conservation of the Stadium of Domizian in Rome. In VIth International Congress on Deterioration and Conservation of Stone, Torun, 12-14 September 1988. Proceedings (pp. 748-756).

Ding Y, Mirao J, Redol P, Dias L, Moita P, Angellini E, Grassini S, Schiavon N (2019) A combined petrographic and geochemical metrological approach to assess the provenance of the building limestone used in the Batalha Monastery (Portugal). BATTISTI, V., \& GALLO, V. (2019). METROLOGY FOR ARCHAEOLOGY AND CULTURAL HERITAGE, 338

Ding Y, Salvador CSC, Caldeira AT, Angelini E, Schiavon N (2021) Biodegradation and microbial contamination of limestone surfaces: an experimental study from Batalha Monastery, Portugal. Corrosion Mater Degradation 2(1):31-45. https://doi.org/10.3390/ cmd2010002

Duffy AP, Perry SH (1996) The mechanisms and causes of Portland limestone decay-a case study. In 8th International Congress on Deterioration and Conservation of stone (Vol. 1, pp. 135-145)

Fassina V (1995) New findings on past treatments carried out on stone and marble monuments' surfaces. Sci Total Environ 167(1-3):185203. https://doi.org/10.1016/0048-9697(95)04580-T

Franzini M, Gratziu C, Wicks E (1984) Patine ad ossalato di calcio su monumenti marmorei. Societa Italiana di Mineralogia e Petrologia 39(1):59-70

Hess D, Coker DJ, Loutsch JM, Russ J (2008) Production of oxalates in vitro by microbes isolated from rock surfaces with prehistoric paints in the lower Pecos region, Texas. Geoarchaeol Intl J 23(1): 3-11. https://doi.org/10.1002/gea.20208

Hubbard CR, Snyder RL (1988) RIR-measurement and use in quantitative XRD. Powder Diffraction 3(2):74-77. https://doi.org/10.1017/ S0885715600013257

Ion RM, Teodorescu S, Știrbescu RM, Bucurică IA, Dulamă ID, Ion ML (2017) Calcium oxalate on limestone surface of heritage buildings.
In Key Engineering Materials (Vol. 750, pp. 129-134). Trans Tech Publications Ltd. https://doi.org/10.4028/www.scientific.net/KEM. 750.129

Kawamura K, Kaplan IR (1987) Motor exhaust emissions as a primary source for dicarboxylic acids in Los Angeles ambient air. Environ Sci Technol 21(1):105-110

Lazzarini L, Salvadori O (1989) A reassessment of the formation of the patina called scialbatura. Stud Conserv 34(1):20-26. https://doi.org/ 10.1179/sic.1989.34.1.20

Palmieri F, Estoppey A, House GL, Lohberger A, Bindschedler S, Chain PS, Junier P (2019) Oxalic acid, a molecule at the crossroads of bacterial-fungal interactions. Adv Appl Microbiol 106:49-77

Perdikatsis V, Brecoulaki H (2008) The use of red and yellow ochres as painting materials in Ancient Macedonia. BAR Intl Ser 1746:559

Rattazzi A, Camaiti M, Salvioni D (1996) The statues of the apostles from the main doorway of the church of the Monastery of Batalha (Portugal): analysis of degradation forms in relation to ancient treatments. In Proceedings of the 8th International Congress on Deterioration and Conservation of Stone, J. Riederer, Editor, Möller Druck und Verlag, Berlin (pp. 101-108)

Rodriguez-Navarro C, Doehne E (1999) Salt weathering: influence of evaporation rate, supersaturation and crystallization pattern. Earth Surface Process Landforms J British Geomorphol Res Group 24(3): 191-209. https://doi.org/10.1002/(SICI)1096-9837(199903)24: 3<191::AID-ESP942>3.0.CO;2-G

Rosado T, Silva M, Galvão A, Mirao J, Candeias A, Caldeira ATC (2016) A first insight on the biodegradation of limestone: the case of the World Heritage Convent of Christ. Appl. Phys.A 122:1012. https:// doi.org/10.1007/s00339-016-0525-6

Sánchez JS, Alves CAS, Romaní JV, Mosquera DF (2009) Origin of gypsum-rich coatings on historic buildings. Water, Air, and Soil Pollution 204(1-4):53. https://doi.org/10.1007/s11270-009-0025-9

Schiavon N (2002) Biodeterioration of calcareous and granitic building stones in urban environments", Natural Stone, Weathering Phenomena, Conservation Strategies and Case Studies, S. Siegesmund, T. Weiss, A. Vollbrecht. https://doi.org/10.1144/ GSL.SP.2002.205.01.15

Schiavon N (2007) Kaolinization of granite in an urban environment. Environ Geol 52(2):399-407. https://doi.org/10.1007/s00254-0060473-0

Soares CM (2001) O restauro do mosteiro da batalha: pedreiras históricas, estaleiro de obras e mestres canteiros. Estaleiro de Obras e Mestres Canteiros, Leiria, Magno Edições

Veiga A, Mirão J, Candeias AJ, Simões Rodrigues P, Martins Teixeira D, Muralha VS, Ginja Teixeira J (2014) Pigment analysis of Portuguese portrait miniatures of 17 th and 18 th centuries by Raman Microscopy and SEM-EDS. J Raman Spectrosc 45(10): 947-957. https://doi.org/10.1002/jrs.4570

Publisher's note Springer Nature remains neutral with regard to jurisdictional claims in published maps and institutional affiliations. 